\title{
Release of multifunctional peptides from kiwicha (Amaranthus caudatus) protein under in vitro simulated gastrointestinal digestion
}

Running title: Multifunctional kiwicha-derived peptides

\author{
Rubén Vilcacundo ${ }^{1,2}$, Cristina Martínez-Villaluenga ${ }^{3}$, Beatriz Miralles ${ }^{1}$, Blanca Hernández- \\ Ledesma $^{1 *}$
}

1 Instituto de Investigación en Ciencias de la Alimentación (CIAL, CSIC-UAM, CEI UAM+CSIC). Nicolás Cabrera, 9. 28049 Madrid, Spain

${ }^{2}$ Laboratorio de Alimentos Funcionales, Facultad de Ciencia e Ingeniería en Alimentos, Universidad Técnica de Ambato. Av. Los Chasquis y Rio Payamino, Ambato, Ecuador

${ }^{3}$ Institute of Food Science, Technology and Nutrition (ICTAN-CSIC), Juan de la Cierva 3, 28006 Madrid, Spain

* Corresponding author: B. Hernández-Ledesma

Nicolás Cabrera, 9. 28049 Madrid, Spain

Phone: +34 910017970

Fax: +34 910017905

e-mail: b.hernandez@,csic.es 


\begin{abstract}
BACKGROUND: The multifactorial origin of many chronic diseases provides a new framework for the development of multifunctional foods. In this study, the effect of in vitro simulated gastrointestinal digestion of kiwicha (Amaranthus caudatus) proteins on the release of multifunctional peptides was evaluated.
\end{abstract}

RESULTS: Gastric digest showed higher angiotensin-I converting enzyme (ACE) inhibitory activity while 60 minutes gastroduodenal digest showed the highest antioxidant, dipeptidyl peptidase IV (DPP-IV), $\alpha$-amylase, and Caco-2 cell viability inhibitory activities. Peptides $>5$ $\mathrm{kDa}$ were more effective inhibiting colon cancer cell viability whereas peptides $<5 \mathrm{kDa}$ were mainly responsible for the antioxidant, ACE, DPP-IV, and $\alpha$-amylase inhibitory activities. Thirteen peptides from amaranth sequenced proteins were identified. The structure-activity relationship analysis of the identified sequences directed to three amaranth fragments, FLISCLL, SVFDEELS, and DFIILE, as potential peptides able to concurrently exert antioxidant capacity and ability to inhibit both ACE and $\alpha$-amylase.

CONCLUSIONS: Five of thirteen peptides identified in kiwicha protein digests show high potential to exert multifunctional properties. Thus, kiwicha proteins might start to gain importance as ingredients of functional foods for the prevention and/or management of chronic diseases related to oxidative stress, hypertension and/or diabetes.

Keywords: bioactive peptides; kiwicha; multifunctional activity; simulated gastrointestinal digestion 


\section{Introduction}

Non-communicable diseases (NCD) are the leading cause of death and disability globally. The majority of NCD (cardiovascular and neurodegenerative disorders, cancer, and diabetes) are generated by four risk factors, with the diet making the biggest contribution. Generally, highly processed foods such as processed meats and sugar-sweetened beverages have harmful effects, whereas bioactive-rich foods like fruits, vegetables, nuts/seeds, beans/legumes, and whole grains have protective effects. ${ }^{1}$ A healthy diet combined with the intake of functional foods may help minimizing or even preventing certain $\mathrm{NCD}^{2}$ Thus, in the last years, the research interest in bioactive food compounds as an alternative to pharmacological treatment has increased.

In addition to their nutritional quality, food proteins are recognized by their role as source of bioactive peptides. These peptides are encrypted in the protein sequences, but once they are released by gastrointestinal digestion and/or food processing, they can exert a wide range of biological functions. This has given rise to intensive research into the potential applications of food-derived multifunctional peptides in the prevention and/or treatment of NCD. ${ }^{3}$

Kiwicha (Amaranthus caudatus) is an ancestral pseudocereal commonly produced in Mexico, Peru and other Andean countries. Its production is rapidly growing around the world due to its agronomical and nutritional value, and its gluten-free nature. Moreover, it has a great nutritional potential as source of lipids (5-13\%), specially unsaturated fatty acids, fiber (11-23\%), minerals, vitamins, and proteins, whose concentration (13-19\%) is higher than that present in cereals. ${ }^{4}$ Amaranth proteins show high digestibility and an excellent balance of essential amino acids such as lysine and sulfur-containing amino acids, which are commonly deficient in traditional cereals and legumes, respectively. ${ }^{5}$ Other studies have reported the presence of bioactive compounds (flavonoids, phenolic acids, anthocyanins, tannins, and phytosterols) in 
amaranth grains. ${ }^{6}$ Thus, the introduction in the diet of amaranth seeds has been associated with health promotion and prevention of $\mathrm{NCD} .^{7}$

Among the bioactive compounds present in amaranth, peptides have gained interest in the last years. The studies have mainly focused on proteins from A. hypochondriacus as source of angiotensin I-converting enzyme (ACE) and dipeptidyl peptidase IV (DPP-IV) inhibitory peptides. ${ }^{89}$ However, studies focused on less broadly exploited amaranth species such as $A$. caudatus (kiwicha) or A. cruentus are very scarce ${ }^{10,11}$ although their use is increasingly promoted in countries such as Ecuador or Peru. ${ }^{12}$ The objective was to bring in a wide approach by evaluating the antioxidant, ACE, DPP-IV, $\alpha$-amylase, and colon cancer cell viability inhibitory activities of kiwicha protein concentrate (KPC) hydrolyzed under in vitro conditions simulating gastrointestinal digestion. Peptide identification and structure-activity analysis were performed with the aim to ascribe the observed biological activities to particular sequences in a realistic way.

\section{Materials and Methods}

\subsection{Materials}

Pepsin from porcine gastric mucosa (EC 3.4.23.1), pancreatin from porcine pancreas (EC 232-468-9), porcine bile extract, the serine proteases inhibitor Pefabloc ${ }^{\circledR}$ SC, ACE (EC 3.4.15.1), fluorescein disodium (FL), 3-[4,5-dimethylthiazol-2-yl]-2,3-diphenyl tetrazolium bromide (MTT), dimethylsulfoxide (DMSO), human recombinant DPP-IV enzyme, potato soluble starch, and porcine pancreatic $\alpha$-amylase (EC 3.2.1.1) were purchased from Sigma-Aldrich (Madrid, Spain). Fluorogenic substrate $o$-aminobenzoylglycyl-p-nitro-l-phenylalanyl-1-proline (Abz-Glyp-Phe $\left.\left(\mathrm{NO}_{2}\right)-\mathrm{Pro}-\mathrm{OH}\right)$ was from Bachem Feinchemikalien (Bubendorf, Switzerland), and 
chromogenic substrate (H-Gly-Pro-p-nitroaniline) from Enzo Life Sciences Inc. (Farmingdale, NY, USA). 2,2'-azobis (2-methylpropionamide)-dihydrochloride (AAPH) and 6-hydroxy2,5,7,8-tetramethylchroman-2-carboxylic acid (Trolox) were from Aldrich (Milwaukee, WI, USA). The rest of chemicals used were of HPLC grade.

\subsection{Preparation of $K P C$}

The KPC was prepared following the protocol of Acosta and coworkers, ${ }^{13}$ with slight modifications. Kiwicha flour (Gramolino, Quito, Ecuador) was suspended in water $(1: 10, \mathrm{w} / \mathrm{v})$ and its $\mathrm{pH}$ was adjusted to 12.0 with $1 \mathrm{M} \mathrm{NaOH}$. The suspension was stirred for $1 \mathrm{~h}$ and centrifuged at $4,500 \mathrm{xg}$ for $30 \mathrm{~min}$ at $25^{\circ} \mathrm{C}$. After adjusting the $\mathrm{pH}$ of the supernatant to 4.0 with $2 \mathrm{M} \mathrm{HCl}$, it was centrifuged at $4,500 \times \mathrm{g}$ during $20 \mathrm{~min}$ at $4^{\circ} \mathrm{C}$. The pellet was dissolved in a small volume of water, neutralized with $0.1 \mathrm{M} \mathrm{NaOH}$ solution, lyophilized, and kept at $-20^{\circ} \mathrm{C}$ until further analyses. The protein content of KPC was determined by the Kjeldahl method.

\subsection{In vitro simulation of gastrointestinal digestion of $K P C$}

KPC was digested following the in vitro harmonized protocol of Minekus et al. ${ }^{14}$ Digest samples were taken at the starting point (K0), after 120 min of gastric digestion (KG120) and after $60 \mathrm{~min}(\mathrm{KD} 60)$ and $120 \mathrm{~min}(\mathrm{KD} 120)$ incubation with pancreatin. Digestion was performed in duplicate. A blank without KPC and containing the mixture of enzymes used at the same concentration was prepared. Digests were subjected to ultrafiltration through a hydrophilic 5000 Da cutoff membrane (Agilent Technologies, Inc., Waldbronn, Germany). Digests and fractions were freeze dried and kept at $-20^{\circ} \mathrm{C}$ until further analyses. The protein content was determined by 
the bicinchoninic acid method (BCA) (Pierce, Rockford, IL, USA), using bovine serum albumin as standard protein.

\subsection{SDS-PAGE}

Samples were dissolved $(0.5 \mathrm{mg}$ of protein $/ \mathrm{mL})$ in sample buffer and heated at $95^{\circ} \mathrm{C}$ for 5 min. $25 \mu \mathrm{L}$ of sample $(12.5 \mu \mathrm{g}$ protein) was loaded on $12 \%$ Bis-Tris polyacrilamide gels (Criterion_XT, Bio-Rad, Hercules, CA, USA). Electrophoretic separations were run at $100 \mathrm{~V}$ for $5 \mathrm{~min}$ and then, at $150 \mathrm{~V}$ for $50 \mathrm{~min}$, using the XT MES running buffer (Bio-Rad) in the Criterion Cell (Bio-Rad). The molecular weight Precision Plus Protein ${ }^{\text {TM }}$ Unstained standard marker (BioRad) was used. Coomasie Blue (Instant blue, Expedeon, Swavesey, UK) was used to stain the gels, and images were taken with a Molecular Imager ${ }^{\circledR}$ VersaDoc $^{\mathrm{TM}}$ MP 5000 system (Bio-Rad) and processed with Quantity One ${ }^{\circledR} 1-\mathrm{D}$ analysis software (Bio-Rad).

\subsection{Measurement of biological activities}

\subsubsection{Angiotensin I-converting enzyme (ACE) inhibitory activity}

In vitro ACE inhibitory activity of digests and fractions was measured using the method described by Quirós et al. ${ }^{15}$ The activity was expressed as $\mathrm{IC}_{50}$ or peptide concentration required to inhibit the ACE activity by $50 \%$, and was determined in duplicate.

\subsubsection{Oxygen radical absorbance capacity (ORAC)}

An oxygen radical absorbance capacity (ORAC) assay was used following the optimized protocol of Hernández-Ledesma and coworkers. ${ }^{16}$ The ORAC value was expressed as $\mu$ mol Trolox equivalents (TE)/mg peptide. Three independent runs were performed for each sample. 


\subsubsection{Colon cancer cell viability inhibitory activity}

Human colorectal cancer Caco-2 cell line was obtained from the American Type Culture Collection (ATCC, Rockville, MD, USA) and grown in Dulbecco's Modified Eagle Medium (DMEM, Biowest, Nuaillé, France), supplemented with 10\% (v/v) fetal bovine serum (FBS, Biowest), 1\% (v/v) non-essential amino acid solution (Lonza Group Ltd), and 1\% (v/v) penicillin/streptomycin/amphotericin B solution (Biowest). Cells were maintained in an incubator under a $5 \% \mathrm{CO}_{2} / 95 \%$ air at $37^{\circ} \mathrm{C}$ and constant humidity changing the medium every two days. The effect of KPC digests and fractions on the viability of Caco-2 cells was evaluated by the MTT assay. Cells were seeded at a density of $5 \times 10^{4}$ cells/well in 96-well plates (Costar, Corning, NY, USA) and incubated for $24 \mathrm{~h}$. Afterwards, cells were treated with KPC digests, fractions or blanks at different concentrations $(0.05-4 \mathrm{mg}$ protein $/ \mathrm{mL})$ for $24 \mathrm{~h}$. Medium was removed, and cells were washed with PBS and incubated with MTT $(0.5 \mathrm{mg} / \mathrm{mL}$, final concentration) for $2 \mathrm{~h}$. After discarding the supernatants, insoluble formazan crystals formed were dissolved in DMSO:ethanol $(1: 1, \mathrm{v} / \mathrm{v})$ and the absorbance was measured at $570 \mathrm{~nm}$ in a FLUOstar OPTIMA plate reader (BMG Labtech Inc., Offenburg, Germany). Results were expressed as $\mathrm{IC}_{50}$ or peptide concentration needed to inhibit $50 \%$ cell viability. Experiments were carried out in triplicate.

\subsubsection{In vitro anti-diabetic activity}

DPP-IV inhibitory activity was measured in 96-well plates following the protocol described by Silveira et al. ${ }^{17} \alpha$-amylase inhibitory activity was determined following the protocol described by Johnson et al. ${ }^{18}$ with some modifications. The results were expressed as $\mathrm{IC}_{50}$ value 
or peptide concentration needed to inhibit $50 \%$ of enzyme activity. Each sample was analyzed in duplicate.

\subsection{Fractionation of the kiwicha protein digest by semi-preparative RP-HPLC}

Semi-preparative RP-HPLC was carried out according to Vilcacundo et al. ${ }^{19}$ with some modifications. A Hi-Pore Reversed Phase RP-318 (250 x $21.5 \mathrm{~mm}$ ) column (Bio-Rad) was used. KD60 was prepared $(10 \mathrm{mg} / \mathrm{mL})$, and the injection volume was $400 \mu \mathrm{L}$. Fractions were eluted at a flow rate of $10 \mathrm{~mL} / \mathrm{min}$, with a linear gradient of solvent $\mathrm{B}$ (acetonitrile: trifluoroacetic acid (TFA), 1000:0.8, v/v) in A (water:TFA, 1000:1, v/v) going from $0 \%$ to $70 \% \mathrm{~B}$ in $40 \mathrm{~min}, 70 \%$ to $100 \% \mathrm{~B}$ in $15 \mathrm{~min}, 15 \mathrm{~min}$ with $100 \% \mathrm{~B}$ and from $100 \% \mathrm{~B}$ to $0 \% \mathrm{~B}$ in $20 \mathrm{~min}$. Each chromatographic run was repeated 50-55 times, and the fractions automatically collected with a Fraction Collector (Model II, Waters, Mildford, MA, USA) were pooled, lyophilized, and stored at $-20^{\circ} \mathrm{C}$ until further analyses. Their peptide content was determined by the BCA method.

2.6. Peptide identification by liquid chromatography coupled to tandem mass spectrometry (LC$M S / M S)$

LC-MS/MS analysis was performed on an Agilent 1100 HPLC System (Agilent Technologies, Waldbron, Germany) connected on-line to an Esquire 3000 ion trap (Bruker Daltonik GmbH, Bremen, Germany), and equipped with an electrospray ionization source. The reverse phase Mediterranea Sea $\mathrm{C}_{18}$ column $(150 \times 2.1 \mathrm{~mm}$ i.d., $5 \mu \mathrm{m}$ particle size) (Teknokroma, Barcelona, Spain) was used. Peptides were eluted with a linear gradient of solvent B (acetonitrile:formic acid, 1000:1, v/v) in A (water:formic acid, 1000:1, v/v) going from $0 \%$ in $45 \%$ in $60 \mathrm{~min}$ at a flow rate of $0.2 \mathrm{~mL} / \mathrm{min}$. The injection volume was $50 \mu \mathrm{L}$. Using Data 
Analysis $^{\mathrm{TM}}$ (version 3.0; Bruker Daltonics), the $\mathrm{m} / \mathrm{z}$ spectral data were processed and transformed to representing mass values. For peptide sequencing, the matched MS/MS spectra were interpreted by using BioTools (version 2.1; Bruker Daltonics), and MASCOT from Matrix Science (Boston, MA, USA), using a homemade database that includes the sequenced proteins of amaranth.

\subsection{Statistical analysis}

Data represent the mean and standard deviation of two or three independent experiments. Data were subjected to one-way analysis of variance (ANOVA) to compare experimental values using Statgraphics 5.0 (Statistical Graphics Corporation, Rockville, Md). Comparison between groups was performed using a Duncan's multiple-range test, and differences were considered significant at $p \leq 0.05$.

\section{Results and Discussion}

\subsection{Effect of gastrointestinal digestion on the kiwicha proteins profile}

The protein concentration of KPC was $53.59 \%$, similar to that $(53.60 \%)$ reported by Escudero and coworkers, using $A$. cruentus flour and $\mathrm{pH} 11.0$ in the extraction step. ${ }^{20} \mathrm{KPC}$ was subjected to an in vitro gastrointestinal digestion. Protein patterns of KPC in each digestion stage (K0, KG120, KD60 and K120) are shown in Figure 1. The protein profile of KPC (lane 1) and K0 (lane 2) showed bands with molecular weights between 6.5 and $150 \mathrm{kDa}$ with the major bands around $78,55,30-35,20-25,17,15,13$, and $11 \mathrm{kDa}$. This profile is in agreement with Gamel et al., that described three bands for albumins, two between 42 and $25 \mathrm{kDa}$ and one below $20 \mathrm{kDa}$, while the globulins showed two bands between 40 and $38 \mathrm{kDa}$, three bands between 27 
and $21 \mathrm{kDa}$ and two bands at 15 and $14 \mathrm{kDa} \cdot{ }^{21}$ Glutelins showed two bands between 67 and 43 $\mathrm{kDa}$, and two bands between 38 and $35 \mathrm{kDa}$, while prolamine bands are found between 34 and 20 $\mathrm{kDa}$. Amaranth proteins were partially hydrolyzed by pepsin, and only bands at 25 and $20 \mathrm{kDa}$ could be noticed (lane 3 in Figure 1). The complete protein degradation was observed after its incubation with pancreatin (lanes 4 and 5). Bands appearing at the gel corresponded to enzymes used in simulated digestive process since they were also visible when digestion blank was analyzed (lane 6).

\subsection{Multifunctionality of kiwicha protein digests}

\subsubsection{Evaluation of biological activity}

Digests were analyzed for the potential multifunctionality of peptides released during simulated digestion. The antioxidant capacity as well as the ability to inhibit ACE, DPP-IV, $\alpha$ amylase, and colon cancer cell viability were measured (Table 1). The highest ORAC value was determined in the digest KD60, indicating that during the first hour of the duodenal phase, potent peroxyl radical scavenging peptides were released. Orsini Delgado et al. determined the antioxidant capacity of amaranth proteins digested under in vitro gastrointestinal conditions. ${ }^{22}$ The ORAC values obtained by these authors $(0.80-1.16 \mu$ mol TE/mg protein) were lower than those found in our study. The differing amaranth species and/or digestion conditions might have caused the release of less active protein hydrolysis products.

K0 showed ACE-inhibitory activity with an $\mathrm{IC}_{50}$ value of $79.13 \pm 1.08 \mu \mathrm{g}$ peptide $/ \mathrm{mL}$. Fritz and coworkers had also found ACE inhibition for the non-hydrolyzed isolate from Amaranthus mantegazzianus, suggesting the presence of preexisting ACE inhibitory peptides in the protein concentrate. ${ }^{23}$ However, Tiengo et al. had reported the practical inactivity of intact 
amaranth proteins since the $\mathrm{IC}_{50}$ value determined for the protein concentrate extracted from defatted A. cruentus flour was $12 \mathrm{mg}$ protein $/ \mathrm{mL} .{ }^{24}$ During the gastric phase, $\mathrm{IC}_{50}$ value was reduced to $39.0 \pm 3.0 \mu \mathrm{g}$ peptide $/ \mathrm{mL}$ while the inhibition rate returned to the initial values, $81.0 \pm$ 10.5 and $88.0 \pm 14.0 \mu \mathrm{g}$ peptide/mL for KD60 and KD120, respectively, indicating that some ACE-inhibitory peptides released by pepsin were degraded by pancreatin. The inhibition was superior to that found in A. cruentus protein concentrate $(439.0 \pm 18 \mu \mathrm{g}$ protein $/ \mathrm{mL})$ digested under simulated conditions. ${ }^{24}$ Recently, globulin and albumin fractions extracted from $A$. hypochondriacus protein and hydrolyzed with Alcalase were analyzed for their ACE inhibitory activity. ${ }^{25}$ These authors reported $\mathrm{IC}_{50}$ values between 925 and $1887 \mu \mathrm{g} / \mathrm{mL}$. Therefore, the Alcalase hydrolysis favored the promotion of ACE inhibitory activity to a less extent than simulated digestion. Lower ACE inhibitory activity was also found for digestion products of soybean protein isolate $\left(\mathrm{IC}_{50}\right.$ of $\left.0.28 \mathrm{mg} / \mathrm{mL}\right){ }^{26}$

KPC at $6.0 \mathrm{mg}$ protein/mL did not show DPP-IV and $\alpha$-amylase inhibitory effects. After the gastric phase, DPP-IV inhibitory activity was observed, although no effects against $\alpha$-amylase at the highest concentration used $(4 \mathrm{mg} / \mathrm{mL})$ were shown (Table 1). Once the gastric digest was subjected to the action of pancreatin, potent DPP-IV inhibitory activity was measured, with similar $\mathrm{IC}_{50}$ values of $0.32 \pm 0.01$ and $0.28 \pm 0.01 \mathrm{mg}$ peptide/mL for $\mathrm{KD} 60$ and $\mathrm{KD} 120$, respectively. These values were lower than those reported for in vitro simulated digests obtained from hemp, pea, rice and soy proteins ${ }^{27}$ although comparable to those reported for quinoa protein peptides released under the same in vitro gastrointestinal digestion conditions. ${ }^{20}$ Velarde-Salcedo et al. also determined the DPP-IV inhibitory activity of amaranth peptides released after simulated gastrointestinal digestion, showing an $\mathrm{IC}_{50}$ of $1.1 \mathrm{mg} / \mathrm{mL} \cdot{ }^{9} \alpha$-amylase inhibitory potency of duodenal digests increased as function of time as indicated the significantly $(p<0.05)$ 
higher $\mathrm{IC}_{50}$ value found in $\mathrm{KD} 60$ compared to $\mathrm{KD} 120$ (Table 1). The $\alpha$-amylase inhibitory activity of peptides released during the duodenal phase was within the range reported for isolated peptides from cumin seed ${ }^{28}$ and pinto bean Protamex hydrolyzates. ${ }^{29}$ As compared to our study in quinoa, peptides formed during kiwicha protein digestion showed lower $\alpha$-amylase inhibitory activity compared to quinoa gastroduodenal digests at $60\left(\mathrm{IC}_{50}=0.53 \mathrm{mg}\right.$ protein $\left./ \mathrm{mL}\right)$ and 120 min of pancreatin hydrolysis $\left(\mathrm{IC}_{50}=0.19 \mathrm{mg}\right.$ protein $\left./ \mathrm{mL}\right) .{ }^{19}$

The potential cytotoxicity in the gastrointestinal tract was evaluated by the MTT protocol, adding the digests to the medium after the Caco-2 cells had grown for $24 \mathrm{~h}$. Digestion blanks without KPC were assayed to evaluate the effect of digestive enzymes and bile salts on cell viability. KG120 showed cytotoxic effects in a dose-dependent manner with a maximum inhibitory activity (80.15\%) observed when Caco-2 cells were exposed to $4 \mathrm{mg}$ peptide/mL of digest, while its corresponding digestion blank did not show cytotoxic effects at this concentration. This result suggests that peptides released by the action of pepsin could be responsible for the observed effects. The cell viability inhibitory activity of gastroduodenal digests significantly increased (between 5- and 9-fold) in comparison with that shown by gastric digest, indicating that more potent peptides inhibiting Caco-2 cell viability were released during incubation with pancreatin. However, the contribution of bile salts or Pefabloc added to the digestion blank cannot be discarded.

\subsubsection{Influence of the molecular weight on the peptide bioactivity}

In order to determine the influence of the molecular weight of peptides on the multifunctionality of kiwicha protein digests, KD60 and KD120 were separated into $>5 \mathrm{kDa}$ and $<5 \mathrm{kDa}$ peptide fractions. Small peptides from food protein sources have been found to have 
high antioxidant activity. ${ }^{30,31}$ In our study, fraction $<5 \mathrm{kDa}$ of KD60 showed the highest peroxyl radical scavenging capacity with an ORAC value of $3.02 \pm 0.13 \mu \mathrm{mol} \mathrm{TE} / \mathrm{mg}$ peptide, that meant $70.5 \%$ of the activity shown by the whole digest. A slight antioxidant activity was measured in the fraction $>5 \mathrm{kDa}$, supporting the hypothesis that the antioxidant capacity of peptides is not only related to their size but also to their amino acid composition, structure, and hydrophobic character, that determines their mechanism and efficiency. ${ }^{32}$ Also, the ultrafiltration method carried out to separate both peptide fractions could allow the passage of low molecular weight active peptides to fraction $>5 \mathrm{kDa}$ that contributed on the observed effects in this fraction.

ACE-inhibitory activity of fractions enriched in short peptides was similar to that determined in the whole digests. This is in agreement with previous studies that have described the ACE-inhibitory activity to be associated with low molecular weight peptides. ${ }^{33}$ As an example, fractionation of thermolysin cherry seed protein hydrolyzate showed that the $<3 \mathrm{kDa}$ peptide fraction was more active ACE inhibitor than the $>3 \mathrm{kDa}$ peptide fraction. ${ }^{34}$ In contrast, no substantial changes in the DPP-IV inhibitory activity derived from the fractionation were observed. Though, the low value determined in the $<5 \mathrm{kDa}$ fraction at the end of simulated digestion (KD120) merits attention because it points to an increased recovery of potent inhibitory peptides at the end of the gastrointestinal digestion. On the other hand, only fractions $<5 \mathrm{kDa}$ showed $\alpha$-amylase inhibition, although the $\mathrm{IC}_{50}$ values were lower in $\mathrm{KD} 120$. These results suggested that potent $\alpha$-amylase inhibitory kiwicha peptides were mainly generated at the end of gastroduodenal digestion. Similarly, a previous study has established 3-5 kDa peptides as the main $\alpha$-amylase inhibitors in quinoa gastroduodenal digests. ${ }^{20}$

Fractions containing $>5 \mathrm{kDa}$ peptides showed higher potency to inhibit Caco-2 cell viability than $<5 \mathrm{kDa}$ peptides. The fraction containing short peptides obtained from KD60 did 
not show any activity at the highest concentration assayed $(2.5 \mathrm{mg}$ protein $/ \mathrm{mL})$. Digestive enzymes retained in fraction $>5 \mathrm{kDa}$ and bile salts that passed through the membrane filter appearing in fraction $<5 \mathrm{kDa}$ could be responsible for the cytotoxic effects shown by fractions collected from the digestion blank. Our results indicate that high molecular kiwicha peptides were more effective inhibiting colon cancer cell proliferation than smaller peptides as it had been reported by González-Montoya et al. for germinated soybean digests. ${ }^{35}$ However, Kannan and coworkers found the $<5 \mathrm{kDa}$ fraction of rice bran hydrolyzates to have higher anti-cancer activity against HepG2 cells than both $5-10$ and $>10 \mathrm{kDa}$ fractions. ${ }^{36}$ Although the greater molecular mobility and diffusivity of low molecular weight peptides has been considered to facilitate their interactions with cancer cell components improving their antiproliferative activity, other aspects such as the amino acid composition and the peptide hydrophobicity could also have a positive impact on the activity of $>5 \mathrm{kDa}$ fraction.

\subsection{Identification of potential bioactive peptides}

KD60 was selected based on its multifunctionality, and fractionated by semi-preparative RP-HPLC (Figure 2). Most of the peptides eluted between 30 and $50 \mathrm{~min}$. Two fractions, named as F-1 and F-2, were collected and analyzed to determine their biological activities (Table 2). Both fractions were found to exert all the bioactivities studied, with F-2 being more active except for $\alpha$-amylase inhibition that showed an $\mathrm{IC}_{50}$ value 2.8 -fold higher than $\mathrm{F}-1$. The ORAC value of F-2 was $4.47 \mu \mathrm{mol} \mathrm{TE} / \mathrm{mg}$ peptide compared to $1.56 \mu \mathrm{mol} \mathrm{TE} / \mathrm{mg}$ peptide calculated for F-1. The $\mathrm{IC}_{50}$ values for ACE, DPP-IV and Caco-2 cell viability inhibition shown by F-2 were between 1.3- and 4.4-fold lower than those determined for F-1. 
Fractions F-1 and F-2 were analyzed by LC-MS/MS in order to identify the peptides potentially responsible for their biological activity. Diverse peptide compounds with molecular mass in the range 500 to $1500 \mathrm{Da}$ were detected. Due to incomplete knowledge of the Amaranthus genome, only some amaranth seed proteins have a reported sequence included in the NCBInr database. Thus, only peptides belonging to those referenced proteins can be identified by this approach. In our study, 13 fragments matched amaranth proteins found in the database, of which five were present in F-1 and eight in F-2 (Table 3). Of these peptides, sequences NRPET, HVIKPPS, and ASANEPEDEN, were within the sequence of peptides (FNRPETT, HVIKPPSRA, and ITASANEPEDN) recently identified by Orsini Delgado et al. ${ }^{11}$ These authors showed an ORAC value of $0.57 \mathrm{mg} / \mathrm{mL}$ for peptide HVIKPPSRA. The quantitative structure activity relationship (QSAR) modeling has demonstrated the relationship between the physicochemical properties at the $\mathrm{C}$-terminal and $\mathrm{N}$-terminal regions and the antioxidant potency, the former being more relevant than the latter. Bulky hydrophobic amino acids at the C-terminal region, polar/charged amino acids at the $\mathrm{C} 1$ position as well as low electronic property at the $\mathrm{N} 1$, N2 positions have also been found to contribute to the antioxidant activity. ${ }^{37}$ Hernández-Ledesma et al. evaluated the ORAC activity of each amino acid, showing that tryptophan, tyrosine, methionine, histidine, and phenylalanine showed peroxyl radical scavenging activity whereas the rest of amino acids had no activity. ${ }^{16}$ Leucine has also been reported to enhance the scavenging activities of peptides. ${ }^{38}$ In our case, peptides containing bulky amino acids, and mainly the peptide containing tyrosine might be responsible for the antioxidant capacity observed.

The ACE-inhibitory activity of long-chain ( $>4$ residues) seems to be mainly determined by the C-terminal tetrapeptide. Moreover, the presence of proline, branched-chain, aromatic, or hydrophobic amino acids in these peptides seem to enhance their inhibitory properties. ${ }^{33}$ Of 
peptides released from kiwicha proteins, eight contain more than two leucine, proline, valine, or histidine residues. Moreover, among them, sequences FLISCLL, SVFDEELS, and DFIILE contained phenylalanine that could also be determinant on their ACE-inhibitory potency.

Proline at the first, second, third, or fourth N-terminal position has been defined as a structural feature determinant on the DPP-IV inhibitory activity. ${ }^{39}$ Moreover, recent in silico studies have shown that potent DPP-IV inhibitory peptides generally contain a branched-chain amino acid or an aromatic residue with a polar group in the side-chain at their N-terminal position. ${ }^{40}$ On basis of these studies, peptides NRPET and VEEGNM, could be the main responsible for the DPP-IV inhibitory activity shown by kiwicha fractions. However, other peptides contained in these fractions that have not been identified as well as their potential interactions might also have a positive influence.

Recently, it has been reported that the aromatic-aromatic interactions (hydrogen bonds, electrostatic and Van der Waals interactions) between food-derived peptides and enzyme residues in the catalytic site seem to be crucial for the inhibition of $\alpha$-amylase activity. ${ }^{41}$ Therefore, the presence of aromatic residues such as phenylalanine, tryptophan, and tyrosine has been established as structural feature of peptides for $\alpha$-amylase inhibition. ${ }^{29,41}$ Peptides derived from pinto bean proteins containing histidine, methionine, leucine, proline, or glycine have been found good $\alpha$-amylase inhibitors. ${ }^{42}$ Most of peptides identified in F-1 (YESGSQ, GGEDE, and NRPET) and F-2 (FLISCLL, TALEPT, HVIKPPS, SVFDEELS, ASANEPDEN, and DFIILE) contained the amino acid residues involved on enzyme binding at N-terminal and C-terminal of the peptide sequence. Position of these amino acids in the peptide sequence might also play an important role on $\alpha$-amylase inhibition. 
Taken together all results and on the basis of the relationship between the structure and bioactivities, peptides identified in fraction F-2 (FLISCLL, SVFDEELS, and DFIILE) have a great potential as multifunctional peptides exerting antioxidant capacity and ability to inhibit both ACE and $\alpha$-amylase. Peptide NRPET (F-1) as inhibitor of DPP-IV and $\alpha$-amylase, and peptide HVIKPPS (F-2) as antioxidant and $\alpha$-amylase inhibitor might also be considered as multifunctional peptides.

The results of the present study demonstrate the role of kiwicha proteins as source of multifunctional peptides released under in vitro conditions simulating gastrointestinal digestion. After sequential incubation with pepsin and pancreatin, potent digests with antioxidant capacity and inhibitory activity against ACE, DPP-IV, and colon cancer cell viability were obtained. These digests also showed moderate $\alpha$-amylase inhibitory activity. Peptides contained in these digests might exert their effects at both local and systemic level after their absorption through the gastrointestinal tract. Low molecular weight peptides were the main responsible for the radical scavenging activity and the activity towards enzymes, while higher size peptides were the main determinant on the cytotoxic effects against colon cancer cells. Thirteen peptides have been identified of which five show high potential to exert multifunctional properties. Thus, kiwicha proteins might start to gain importance as ingredients for functional foods for the prevention and/or management of chronic diseases related to oxidative stress, hypertension and/or diabetes. However, these findings should be validated using the individual peptides to confirm their multifunctionality and investigate their bioavailability and mechanism of action. 


\section{Acknowledgments}

This work has received financial support from Ministry of Economy and Competitiveness (MINECO, Spain) through the projects AGL2015-66886-R and AGL2013-43247-R. R.V. acknowledges Universidad Técnica de Ambato (UTA, Ecuador) for his fellowship (23-CU-P2015). 


\section{References}

1. Micha R, Shulkin ML, Peñalvo JL, Khatibzadeh S, Singh GM, Rao M, et al., Etiologic effects and optimal intakes of foods and nutrients for risk of cardiovascular diseases and diabetes: Systematic reviews and meta-analyses from the nutrition and chronic diseases expert group (NutriCoDE). PLoS ONE 12 (2017).

2. Jew S, Abumweis SS and Jones PJH, Evolution of the human diet: Linking our ancestral diet to modern functional foods as a means of chronic disease prevention. J Med Food 12:925934 (2009).

3. Cicero AFG, Fogacci F and Colletti A, Potential role of bioactive peptides in prevention and treatment of chronic diseases: a narrative review. Brit J Pharmacol 174:1378-1394 (2017).

4. Alvarez-Jubete L, Arendt EK and Gallagher E, Nutritive value and chemical composition of pseudocereals as gluten-free ingredients. Int J Food Sci Nutr 60:240-257 (2009).

5. Gorinstein S, Pawelzik E, Delgado-Licon E, Haruenkit R, Weisz M and Trakhtenberg S, Characterisation of pseudocereal and cereal proteins by protein and amino acid analyses. $J$ Sci Food Agric 82:886-891 (2002).

6. Caselato-Sousa VM and Amaya-Farfán J, State of knowledge on Amaranth grain: A comprehensive review. J Food Sci 77:R93-R104 (2012).

7. Rastogi A and Shukla S, Amaranth: a new millennium crop of nutraceutical values. Crit Rev Food Sci Nutr 53:109-125 (2013).

8. Silva-Sánchez C, Barba De La Rosa AP, León-Galván MF, De Lumen BO, De LeónRodríguez A and González De Mejia E, Bioactive peptides in amaranth (Amaranthus hypochondriacus) seed. J Agric Food Chem 56:1233-1240 (2008). 
9. Velarde-Salcedo AJ, Barrera-Pacheco A, Lara-González S, Montero-Morán GM, DíazGois A, González de Mejia E, et al., In vitro inhibition of dipeptidyl peptidase IV by peptides derived from the hydrolysis of amaranth (Amaranthus hypochondriacus L.) proteins. Food Chem 136:758-764 (2013).

10. Soares RAM, Mendonça S, de Castro LÍA, Menezes ACCCC and Arêas JAG, Major peptides from Amaranth (Amaranthus cruentus) protein inhibit HMG-CoA reductase activity. Int J Mol Sci 16:4150-4160 (2015).

11. Orsini Delgado MC, Nardo A, Pavlovic M, Rogniaux H, Añón MC and Tironi VA, Identification and characterization of antioxidant peptides obtained by gastrointestinal digestion of amaranth proteins. Food Chem 197:1160-1167 (2016).

12. Alvarez-Jubete L, Arendt EK and Gallagher E, Nutritive value of pseudocereals and their increasing use as functional gluten-free ingredients. Trends Food Sci Technol 21:106-113 (2010).

13. Acosta C, Carpio C, Vilcacundo R and Carrillo W, Identification of proteins isolate from amaranth (Amaranthus caudatus) by sodium dodecyl sulfate-polyacrylamide gel electrophoresis with water and $\mathrm{NaCl} 0.1 \mathrm{M}$ solvents. Asian J Pharm Clin Res 9 (2016).

14. Minekus $\mathrm{M}$, Alminger $\mathrm{M}$, Alvito $\mathrm{P}$, Ballance $\mathrm{S}$, Bohn $\mathrm{T}$, Bourlieu $\mathrm{C}$, et al., A standardised static in vitro digestion method suitable for food-an international consensus. Food Funct 5:1113-1124 (2014).

15. Quirós A, Contreras MM, Ramos M, Amigo L and Recio I, Stability to gastrointestinal enzymes and structure-activity relationship of $\beta$-casein-peptides with antihypertensive properties. Peptides 30:1848-1853 (2009). 
16. Hernández-Ledesma B, Dávalos A, Bartolomé B and Amigo L, Preparation of antioxidant enzymatic hydrolysates from $\alpha$-lactalbumin and $\beta$-lactoglobulln. Identification of active peptides by HPLC-MS/MS. J Agric Food Chem 53:588-593 (2005).

17. Silveira ST, Martínez-Maqueda D, Recio I and Hernández-Ledesma B, Dipeptidyl peptidase-IV inhibitory peptides generated by tryptic hydrolysis of a whey protein concentrate rich in $\beta$-lactoglobulin. Food Chem 141:1072-1077 (2013).

18. Johnson MH, Lucius A, Meyer T and Gonzalez de Mejia E, Cultivar evaluation and effect of fermentation on antioxidant capacity and in vitro inhibition of $\alpha$-amylase and $\alpha$-glucosidase by highbush blueberry (Vaccinium corombosum). J Agric Food Chem 59:8923-8930 (2011).

19. Vilcacundo R, Martínez-Villaluenga C and Hernández-Ledesma B, Release of dipeptidyl peptidase IV, $\alpha$-amylase and $\alpha$-glucosidase inhibitory peptides from quinoa (Chenopodium quinoa Willd.) during in vitro simulated gastrointestinal digestion. J Funct Foods 35:531-539 (2017).

20. Escudero NL, De Arellano ML, Luco JM, Giménez MS and Mucciarelli SI, Comparison of the chemical composition and nutritional value of Amaranthus cruentus flour and its protein concentrate. Plant Foods Hum Nutr 59:15-21 (2004).

21. Gamel TH, Linssen JP, Mesallem AS, Damir AA and Shekib LA, Effect of seed treatments on the chemical composition and properties of two amaranth species: Starch and protein. J Sci Food Agric 85:319-327 (2005).

22. Orsini Delgado MC, Tironi VA and Añón MC, Antioxidant activity of amaranth protein or their hydrolysates under simulated gastrointestinal digestion. LWT - Food Sci Technol 44:1752-1760 (2011). 
23. Fritz M, Vecchi B, Rinaldi G and Añón MC, Amaranth seed protein hydrolysates have in vivo and in vitro antihypertensive activity. Food Chem 126:878-884 (2011).

24. Tiengo A, Faria $\mathrm{M}$ and Netto FM, Characterization and ACE-inhibitory activity of Amaranth proteins. J Food Sci 74:H121-H126 (2009).

25. Soriano-Santos $\mathrm{J}$ and Escalona-Buendía H, Angiotensin I-Converting enzyme inhibitory and antioxidant activities and surfactant properties of protein hydrolysates as obtained of Amaranthus hypochondriacus L. grain. J Food Sci Technol 52:2073-2082 (2015).

26. Lo WMY and Li-Chan ECY, Angiotensin I converting enzyme inhibitory peptides from in vitro pepsin-pancreatin digestion of soy protein. J Agric Food Chem 53:3369-3376 (2005).

27. Nongonierma $\mathrm{AB}$ and FitzGerald RJ, Investigation of the potential of hemp, pea, rice and soy protein hydrolysates as a source of dipeptidyl peptidase IV (DPP-IV) inhibitory peptides. Food Dig 6:19-29 (2015).

28. Siow HL, Tye GJ and Gan CY, Pre-clinical evidence for the efficacy and safety of $\alpha$ amylase inhibitory peptides from cumin (Cuminum cyminum) seed. $J$ Funct Foods 35:216-223 (2017).

29. Ngoh YY, Tye GJ and Gan CY, The investigation of $\alpha$-amylase inhibitory activity of selected Pinto bean peptides via preclinical study using AR42J cell. J Funct Foods 35:641-647 (2017).

30. Tang CH, Peng J, Zhen DW and Chen Z, Physicochemical and antioxidant properties of buckwheat (Fagopyrum esculentum Moench) protein hydrolysates. Food Chem 115:672-678 (2009).

31. Liu R, Xing L, Fu Q, Zhou GH and Zhang WG, A review of antioxidant peptides derived from meat muscle and by-products. Antioxidants 5 (2016). 
32. Gallego M, Mora L, Hayes M, Reig M and Toldrá F, Effect of cooking and in vitro digestion on the antioxidant activity of dry-cured ham by-products. Food Res Int 97:296-306 (2017).

33. Aluko RE, Structure and function of plant protein-derived antihypertensive peptides. Curr Opin Food Sci 4:44-50 (2015).

34. García MC, Endermann J, González-García E and Marina ML, HPLC-Q-TOF-MS Identification of antioxidant and antihypertensive peptides recovered from cherry (Prunus cerasus L.) subproducts. J Agric Food Chem 63:1514-1520 (2015).

35. González-Montoya M, Hernández-Ledesma B, Silván JM, Mora-Escobedo R and Martínez-Villaluenga $\mathrm{C}$, Peptides derived from in vitro gastrointestinal digestion of germinated soybean proteins inhibit human colon cancer cells proliferation and inflammation. Food Chem 242:75-82 (2018).

36. Kannan A, Hettiarachchy N, Johnson MG and Nannapaneni R, Human colon and liver cancer cell proliferation inhibition by peptide hydrolysates derived from heat-stabilized defatted rice bran. J Agric Food Chem 56:11643-11647 (2008).

37. Li YW and $\mathrm{Li} \mathrm{B}$, Characterization of structure-antioxidant activity relationship of peptides in free radical systems using QSAR models: Key sequence positions and their amino acid properties. J Theor Biol 318:29-43 (2013).

38. Alemán A, Giménez B, Pérez-Santin E, Gómez-Guillén MC and Montero P, Contribution of Leu and Hyp residues to antioxidant and ACE-inhibitory activities of peptide sequences isolated from squid gelatin hydrolysate. Food Chem 125:334-341 (2011).

39. Pieter BJ-W, Protein hydrolysate enriched in peptides inhibiting DPP-IV and their use. Patent WO2006068480A2 (2006). 
40. Nongonierma AB and Fitzgerald RJ, An in silico model to predict the potential of dietary proteins as sources of dipeptidyl peptidase IV (DPP-IV) inhibitory peptides. Food Chem 165:489-498 (2014).

41. Siow HL and Gan CY, Extraction, identification, and structure-activity relationship of antioxidative and $\alpha$-amylase inhibitory peptides from cumin seeds (Cuminum cyminum). $J$ Funct Foods 22:1-12 (2016).

42. Ngoh YY, Lim TS and Gan CY, Screening and identification of five peptides from pinto bean with inhibitory activities against $\alpha$-amylase using phage display technique. Enz Microb Technol 89:76-84 (2016). 


\section{Figure legends}

Figure 1. Characterization of the kiwicha protein digests obtained after an in vitro simulated gastrointestinal digestion by sodium dodecyl sulfate polyacrylamide gel electrophoresis (SDSPAGE) under reducing conditions. MW: molecular weight marker; Lane 1: kiwicha protein concentrate (KPC), Lane 2: KPC digest at time 0 (K0), Lane 3: KPC gastric digest at $120 \mathrm{~min}$ (KG120), Lane 4: KPC gastroduodenal digest at $60 \mathrm{~min}$ (KD60), Lane 5: KPC gastroduodenal digest at 120 min (KD120), Lane 6: Digestion blank with digestive enzymes.

Figure 2. Fractionation by preparative RP-HPLC of the kiwicha protein concentrate (KPC) gastroduodenal digest at $60 \mathrm{~min}(\mathrm{KD} 60)$. Collected fractions are termed with $\mathrm{F}$ followed by a number. 
Table 1. Antioxidant activity and ACE, DPP-IV, $\alpha$-amylase, and colon cancer Caco-2 cells viability inhibitory activities of gastric and gastroduodenal digests of KPC and their fractions $>$ and $<5 \mathrm{kDa}$

\begin{tabular}{|c|c|c|c|c|c|c|c|}
\hline \multirow[t]{2}{*}{ Digest } & \multirow[t]{2}{*}{ Fraction } & \multirow{2}{*}{$\begin{array}{l}\text { Antioxidant activity } \\
\text { (ORAC, } \mu \mathrm{mol} \\
\text { TE/mg peptide) }\end{array}$} & \multirow{2}{*}{$\begin{array}{l}\text { ACE inhibition } \\
\text { (IC50, } \mu \mathrm{g} \\
\text { peptide/mL) }\end{array}$} & \multirow{2}{*}{$\begin{array}{c}\text { DPP-IV inhibition } \\
\text { (IC50- mg } \\
\text { peptide/mL) }\end{array}$} & \multirow{2}{*}{$\begin{array}{c}\text { a-amylase } \\
\text { inhibition } \\
(\text { IC } 50-\mathbf{m g} \\
\text { peptide/mL) }\end{array}$} & \multicolumn{2}{|c|}{$\begin{array}{c}\text { Caco-2 cell viability } \\
\text { inhibition } \\
\left(\text { IC }_{50}-\text { mg peptide/mL) }\right.\end{array}$} \\
\hline & & & & & & Blank & Sample \\
\hline K0 & $\begin{array}{l}\text { Whole } \\
\text { digest }\end{array}$ & $0.38 \pm 0.02^{\mathrm{a}}$ & $79.13 \pm 1.08^{\mathrm{b}}$ & n.d. ${ }^{\ddagger}$ & n.d. ${ }^{\ddagger}$ & n.d. ${ }^{+}$ & n.d. ${ }^{+}$ \\
\hline KG120 & $\begin{array}{l}\text { Whole } \\
\text { digest }\end{array}$ & $1.51 \pm 0.01^{\mathrm{c}}$ & $39.00 \pm 2.99^{\mathrm{a}}$ & $0.66 \pm 0.01^{\mathrm{d}}$ & n.d. ${ }^{+}$ & n.d. ${ }^{+}$ & $0.72 \pm 0.01^{\mathrm{e}}$ \\
\hline \multirow[t]{3}{*}{ KD60 } & $\begin{array}{l}\text { Whole } \\
\text { digest }\end{array}$ & $4.28 \pm 0.11^{\mathrm{f}}$ & $81.00 \pm 10.53^{b}$ & $0.32 \pm 0.01^{\mathrm{b}}$ & $2.73 \pm 0.02^{\mathrm{d}}$ & $\begin{array}{c}1.24^{ \pm} \\
0.04^{\mathrm{g}}\end{array}$ & $\begin{array}{l}0.08 \pm \\
0.002^{\mathrm{a}}\end{array}$ \\
\hline & $\mathrm{F}>5 \mathrm{kDa}$ & $0.99 \pm 0.03^{\mathrm{b}}$ & $133.74 \pm 2.55^{\mathrm{c}}$ & $0.46 \pm 0.01^{\mathrm{c}}$ & n.d. ${ }^{*}$ & $\begin{array}{l}0.46 \pm \\
0.01^{\mathrm{d}}\end{array}$ & $0.33 \pm 0.03^{\mathrm{c}}$ \\
\hline & $\mathrm{F}<5 \mathrm{kDa}$ & $3.02 \pm 0.13^{\mathrm{e}}$ & $75.61 \pm 5.77^{b}$ & $0.45 \pm 0.03^{c}$ & $1.81 \pm 0.05^{\mathrm{b}}$ & $\begin{array}{c}0.80 \pm \\
0.01^{\mathrm{f}}\end{array}$ & n.d. ${ }^{*}$ \\
\hline \multirow[t]{3}{*}{ KD120 } & $\begin{array}{l}\text { Whole } \\
\text { digest }\end{array}$ & $3.03 \pm 0.06^{\mathrm{e}}$ & $88.01 \pm 13.96^{\mathrm{b}}$ & $0.28 \pm 0.01^{\mathrm{ab}}$ & $2.45 \pm 0.01^{\mathrm{c}}$ & $\begin{array}{c}1.24 \pm \\
0.04^{\mathrm{g}}\end{array}$ & $0.14 \pm 0.01^{\mathrm{ab}}$ \\
\hline & $\mathrm{F}>5 \mathrm{kDa}$ & $0.98 \pm 0.08^{\mathrm{b}}$ & $181.85 \pm 6.12^{\mathrm{d}}$ & $0.68 \pm 0.07^{\mathrm{d}}$ & n.d. ${ }^{*}$ & $\begin{array}{c}0.46 \pm \\
0.01^{\mathrm{d}}\end{array}$ & $0.19 \pm 0.01^{\mathrm{b}}$ \\
\hline & $\mathrm{F}<5 \mathrm{kDa}$ & $2.27 \pm 0.12^{\mathrm{d}}$ & $83.90 \pm 6.81^{b}$ & $0.19 \pm 0.01^{\mathrm{a}}$ & $0.84 \pm 0.03^{\mathrm{a}}$ & $\begin{array}{c}0.80 \pm \\
0.01^{\mathrm{f}}\end{array}$ & $1.76 \pm 0.11^{\mathrm{h}}$ \\
\hline
\end{tabular}

a-g: Different lowercase letters in each biological activity indicate significant differences among samples $(p<0.05$, Duncan test)

n.d. : No inhibitory effect observed at the highest concentration used $(6 \mathrm{mg} / \mathrm{mL})$

n.d. ${ }^{+}$: No inhibitory effect observed at the highest concentration used $(4 \mathrm{mg} / \mathrm{mL})$

n.d. ${ }^{*}$ : No inhibitory effect observed at the highest concentration used $(2.5 \mathrm{mg} / \mathrm{mL})$

TE: Trolox equivalents 
Table 2. Antioxidant activity and ACE, DPP-IV, $\alpha$-amylase and colon cancer Caco-2 cells viability inhibitory activities of fractions collected by RP-HPLC from gastroduodenal digests of kiwicha protein concentrate (KPC) for 60 min (KD60)

\begin{tabular}{|c|c|c|c|c|c|}
\hline Fraction & $\begin{array}{c}\text { Antioxidant } \\
\text { activity (ORAC, } \\
\mu \text { mol TE/mg } \\
\text { protein) }\end{array}$ & $\begin{array}{c}\text { ACE inhibition } \\
\left(\mathrm{IC}_{50}, \mu \mathrm{g} \text { protein } / \mathrm{mL}\right)\end{array}$ & $\begin{array}{c}\text { DPP-IV inhibition } \\
\text { (IC50, mg } \\
\text { protein } / \mathrm{mL})\end{array}$ & $\begin{array}{l}\alpha \text {-amylase inhibition } \\
\text { (IC50, mg protein/mL) }\end{array}$ & $\begin{array}{c}\text { Caco-2 cell viability } \\
\text { inhibition } \\
\text { (IC50, mg protein } / \mathrm{mL})\end{array}$ \\
\hline F-1 & $1.56 \pm 0.13^{\mathrm{a}}$ & $359.47 \pm 0.52^{b}$ & $0.38 \pm 0.04^{b}$ & $0.42 \pm 0.03^{\mathrm{a}}$ & $1.17 \pm 0.14^{\mathrm{a}}$ \\
\hline $\mathrm{F}-2$ & $4.47 \pm 0.39^{b}$ & $81.47 \pm 7.61^{\mathrm{a}}$ & $0.18 \pm 0.01^{\mathrm{a}}$ & $1.17 \pm 0.05^{\mathrm{b}}$ & $0.87 \pm 0.08^{\mathrm{a}}$ \\
\hline
\end{tabular}

a-b: Different lowercase letters in each column indicate significant differences among samples $(p<0.05$, Duncan test)

TE: Trolox equivalents 
Table 3. Peptides identified by HPLC-MS/MS in the fractions F-1 and F-2 collected from kiwicha protein concentrate (KPC) after gastroduodenal digestion for $60 \mathrm{~min}(\mathrm{KD} 60)$.

\begin{tabular}{|c|c|c|c|c|c|c|}
\hline Fraction & Observed mass & Calculated mass & Sequence & Fragment & Source protein & $\begin{array}{c}\text { NCBI Accession } \\
\text { number }\end{array}$ \\
\hline \multirow[t]{5}{*}{ F-1 } & 669.30 & 669.26 & YESGSQ & $f(130-135)$ & \multirow{3}{*}{ 11S Globulin } & \multirow{3}{*}{ CAA57633.1 } \\
\hline & 505.17 & 505.16 & GGEDE & $f(139-143)$ & & \\
\hline & 615.31 & 615.29 & NRPET & $f(479-483)$ & & \\
\hline & 614.39 & 614.34 & QQQLV & $f(254-258)$ & \multirow{2}{*}{ Acetylate synthase } & \multirow{2}{*}{ AAK50821.1 } \\
\hline & 517.29 & 517.22 & ACDIP & $f(606-610)$ & & \\
\hline \multirow[t]{8}{*}{ F-2 } & 807.40 & 807.45 & FLISCLL & $f(22-28)$ & \multirow{4}{*}{ 11S Globulin } & \multirow{4}{*}{ CAA57633.1 } \\
\hline & 630.25 & 630.32 & TALEPT & $f(56-61)$ & & \\
\hline & 776.52 & 776.45 & HVIKPPS & $\mathrm{f}(288-294)$ & & \\
\hline & 924.49 & 924.40 & SVFDEELS & $f(402-409)$ & & \\
\hline & 945.33 & 945.36 & ASANEPDEN & $\mathrm{f}(81-89)$ & \multirow{2}{*}{ Albumin 1} & \multirow{2}{*}{ 1JLY_B } \\
\hline & 677.26 & 677.26 & VEEGNM & $f(103-108)$ & & \\
\hline & 748.40 & 748.40 & DFIILE & $f(56-61)$ & \multirow{2}{*}{ Polyamine oxidase } & \multirow{2}{*}{ AAM43922.1 } \\
\hline & 630.24 & 630.32 & EVEAAI & $f(133-138)$ & & \\
\hline
\end{tabular}




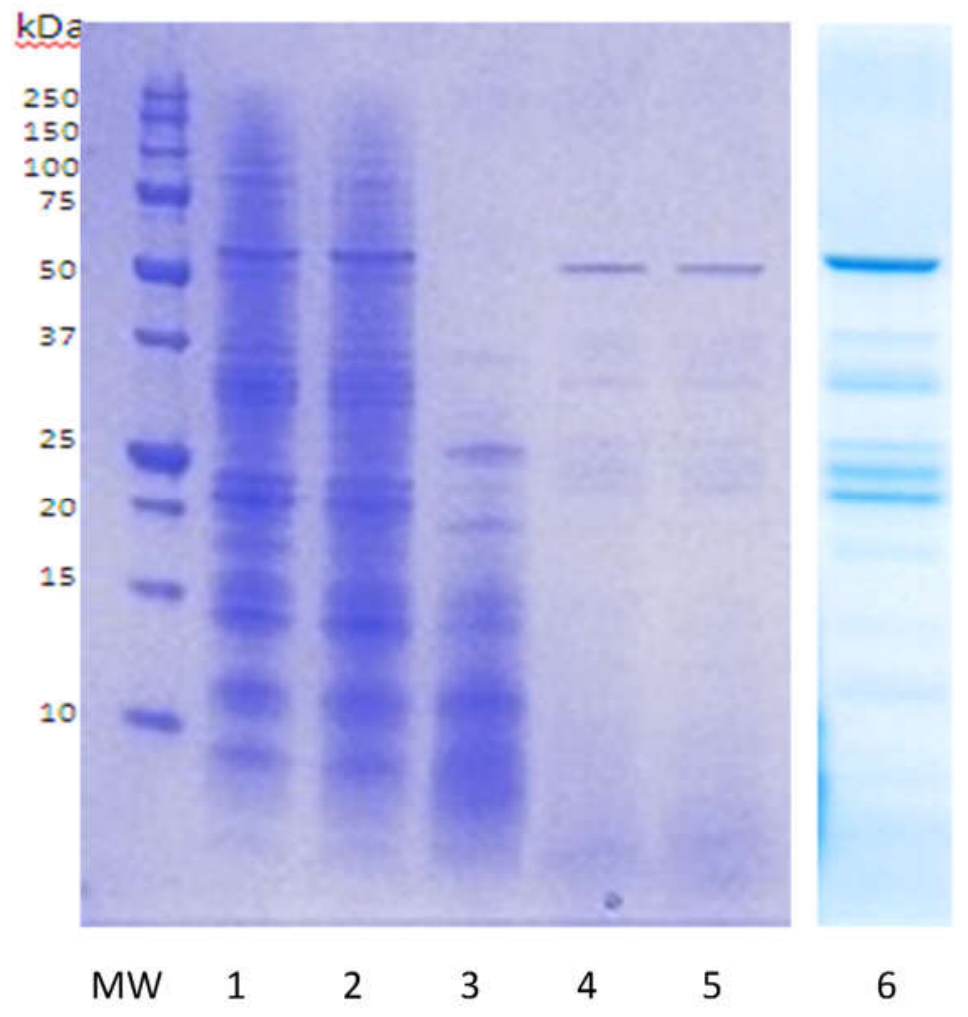

Figure 1 


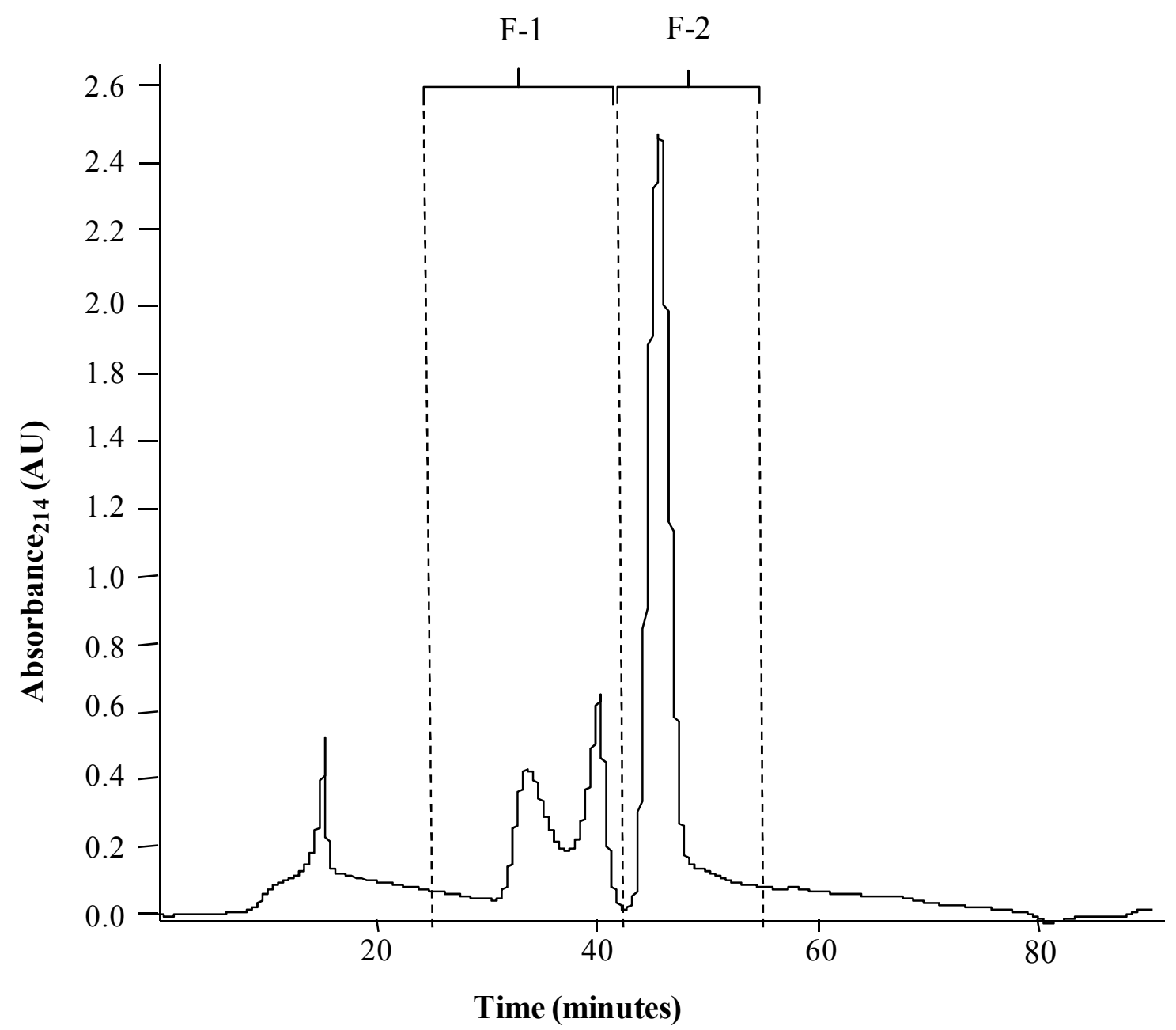

